\title{
TECHNOLOGICAL CHANGES IN DEVELOPED AND DEVELOPING ECONOMIES AND ECOLOGICAL CONSEQUENCE
}

\author{
Faig AGHABALAYEV \\ Sichuan University, People's Republic of China \\ Jiang Xiao RAN \\ Sichuan University, People's Republic of China
}

\section{Introduction}

Economists define technological change as a shift to the new production function that results from an increase in the efficiency of a process or a product. It becomes a primary source for economic development. Technological change in the views of scholars presents a positive transformation, which arrives in the wave of making innovations. In contrast, geographers have become cautious regarding technology changes and their social and environmental impacts on human lives (Kitchin and Thrift, 2009).

Economists agree that higher spending on research and development (R\&D) positively correlates with productivity gains, a higher level of innovations, and growth (Marangoni and Tavoni, 2014). According to neoclassical models, improved productivity is achieved by efficiency gains in 
inputs. Endogenous growth models present technological changes and interaction with the model, while the exogenous introduction of productivity gains is conducted in standard growth models. Technology changes from endogenous models reveal that higher investment in input costs increases the input-saving and productivity gains. Therefore, manipulation of price signal, occurring either from a market-based instrument (subsidies or taxes), or centralized system of control and command (regulations, green R\&D) and their policies, or a combination of both, planners and policymakers can direct for technological changes (Naqvi and Stockhammer, 2018). Following the same logic, climate change models show a discussion about shifting resources towards the green sector from a brown sector to enable a low emission economy transition.

The industrial revolution in the earliest $19^{\text {th }}$ century in Britain saved it from an ecological crisis. The innovative new technologies have alleviated Euro-American anxieties. Different technological optimism versions presented by Marx and Ricardo were soon reincarnated in warnings concerning coal depletion. According to Hornborg (2014), economists in the present century dismiss the pessimism of Malthus and Jevons and concerns of peak oil, as they express faith in human ingenuity. Global warming and peak oil threats are increasingly acknowledged and countered with the future visions of solar power-based civilization. Several doubts and concerns remain with the feasibility of solar power as a solution to the global energy crisis, whether it should be viewed as unrealistic. Some Marxists have severe analytical questions regarding the association between economic value and thermodynamics (Schwartzman, 2008).

Recent policy debates on climate change topics show an increased interest in handling climate changes and their consequences. However, understanding how technologies are diffused is minimal around the globe remains unaddressed. Comin et al. (2012) consider that the lack of datasets that detail the direct diffusion of technologies worldwide is still challenging and requires immediate research to bridge the gap identified in the literature. Vega and Mandel (2018) emphasized the use of wind energy datasets. Several clean development mechanism (CDM) projects have been directed towards the emerging economies, including Brazil, China, 
and India. This leaves significant space for the other developing economies to analyze the approaches from dynamic aspects of technology diffusion and their consequences on climate. Earlier studies use the data of projects for a short period that cannot present a broader view of influencing technologies.

To implement this study empirically, we construct a panel data of 10 years (2010-2019) that combines information on the innovation, GDP, ICT, and Total RD\&D indicators from Panel data of the Paris Agreement. Given the data of randomly selected eight countries from each developed and developing economies, we focus on empirical tests of the hypothesis and compare the technological changes and their consequences on climatic changes in two categories of countries. Our work offers the first empirical evidence on the role of technological changes on the climate and subsequent effects on human lives. This study's results show high skewness and kurtosis test values for Total RD\&D budget allocation indicator, which require future interventions to make them low for a linear distribution between different economies.

The remainder of this paper is organized as follows. Section 2 aims to review and summarize the related literature on a research topic. Section 3 describes the data and methodology of the proposed research. Section 4 presents the results and their discussion, and section 5 concludes the paper with future research implications.

\section{Literature Review}

Tsai et al. (2018) stated that companies in the high-technology market constantly renew the technological bases. Technology acquisition is subject to careful analysis. This research suggested a multifactorial analysis considering the technological capabilities, environmental risk factors, and market capabilities. A dataset consisting of 205 instances of cooperation between fast technology followers and technology holders from the LED industry was sourced to analyze the proposed research. The results showed that fast-following firms with more outstanding $R \& D$ and technological similarities preferred to choose the high resource commitments. However, companies in cooperation require a level of technological overlap to exchange and accelerate the development. 
This type of cooperation creates better opportunities to learn and acquire technologies. Novak (2020) revealed that technological efficiency brought changes in all major sectors of 13 central and southeastern European countries. These sectors showed a decrease in employment due to technological efficiency. Among these sectors, manufacturing is negatively influenced by these factors, such as European level investment and high openness. However, productivity has not shown adverse impacts on the sustainability of workplaces.

Global climate changes have embraced environment sound technologies. These technologies have shown their role in implementing mitigation and adaptation strategies. Oh (2019) attempted to unpack the technology transfer and development negotiation as a part of the Paris Agreement. Based on the theoretical basis of discursive contestation between structuralism and neoliberalism, this study mainly focused on three dimensions: marketization, de-regulatory, and privatization. They may adopt contestant policy options to see whether the Paris agreement is skewed to the developing and developed economies.

In an earlier work, Badunenko et al. (2008) compared the results with another research by Kumar and Russell (2002). They found that technological change was the leading cause behind the divergence of rich and poor. On the contrary, Kumar and Russell (2002) concluded that capital deepening was the primary reason behind the growth and changes throughout the world. This might be because there was lesser technological development before the 1990s, and structural changes occurred afterward, and the world saw the high-tech boom.

Cecere et al. (2019) studied the technological opportunities and their roles to bring green ICT innovation. They have tested whether companies from low-opportunity technological areas are less likely to the innovations or change their direction to gain technological changes. They constructed a dataset for 1992-2009 from the German Innovation Panel to verify the proposed research. Results of applying the general method of moment's estimators supported the research hypothesis that low-opportunity companies were less innovative but more interested in shift to Green ICT innovation. 
Still, we need policy interventions to reach particular green growth and development levels in countries with low technological opportunities.

Court (2018) proposed applying the theoretical thermo-evolutionary technique to reveal the economic growth and technological changes concerning energy capturing and dissipation. The results also showed that energy was central to accomplish the successive phases of economic development and technological changes throughout human history. The proposed research reveals that the conventional theories need to acknowledge energy's role in economic development.

Contemporary studies find the causal relationship between economic growth and climate degradation in several Asian countries. Asghar et al. (2019) also worked on the same subject and collected thirty years (19862015) data. They incorporated Panel autoregressive distributive lag model (P-ARDL) with the Pedroni co-integration method. P-ARDL based on estimators is mainly used to determine the long-run association between variables. ARDL (p, q) expresses the lags of the dependent variable (p), and an independent variable (q), respectively. The Pedroni co-integration method aims to resolve cross-sectional dependency and heterogeneity by incorporating the precise parameters that permit individual members to make variations across parameters.

The role and impacts of information and communication technologies (ICT) were analyzed regarding developed, emerging, and developing countries. They conducted an analysis on a dataset of 59 countries for fifteen years (1995-2010). There is a special connection between GDP growth and ICT. There is a lot of ecological change happening in the last few years, and previous studies do not depict the broad view of recent information about technologies and their impacts. Niebel (2018) stated that there were no statistical differences in the ICT elasticity between three categories of countries. This indicated that emerging and developing economies were behind in gaining more from the ICT investment than the developed countries. However, we need to revisit the developed and developing economies in terms of technology adaptation in the last ten years. 


\section{Data and Methodology}

This paper's primary data is under the license of UN, IEA, WorldBank, and EJAtlas, and can be accessed from the Kaggle website. It has been original developed under the Paris agreement and has been maintained by the respective authorities.

The dataset contains a lot of information on the Paris agreement, climate action tracker (CAT), country metadata, global innovation in ICT, energy technology 'research, development, demonstration' (RD\&D budget), etc. We have used data from developed and developing countries for the years 2010 - 2019. The reason behind restricting sample data from 2010 to 2019 is that some values are missing for the RD\&D budget and other subsamples.

\subsection{Focused Developed and Developing Countries}

The primary goal of this study is to compare the developed and developing economies in the context of technological changes. It is essential to include the countries from both categories of economies. The category of countries is based on income groups derived from 'gross domestic product (GDP) and 'per capita income (PCI).

Table 1 shows the GDP data of chosen countries from two categories. The GDP data is given in \$ billions. As shown in Table 1, there are eight countries for each category of developed and developing countries. There is a large gap between the GDP of the USA as a developed country and Albania (ALB), with the smallest GDP as a developing country. The same is not valid for the split between developed and developing countries. China (CHN), as a developing country with the 14342.90 \$ billion GDP, is followed by Brazil (1839.80 \$ billions) and Russia (1699.99 \$ billions) from the same list of developing countries. 
A threshold test can be used to confirm the outliers' frequencies between developed and developing countries (Hansen 2000).

\begin{tabular}{|c|c|c|c|c|c|c|c|c|}
\hline \multicolumn{4}{|c|}{ Developed Countries } & & \multicolumn{3}{|c|}{ Developing Countries } & \\
\hline 1 & $\begin{array}{l}\text { Commonwealth } \\
\text { of Australia }\end{array}$ & AUS & $\begin{array}{l}\text { High } \\
\text { income }\end{array}$ & 1392.70 & $\begin{array}{l}\text { Federative } \\
\text { Republic of } \\
\text { Brazil }\end{array}$ & BRA & $\begin{array}{l}\text { Upper } \\
\text { middle } \\
\text { income }\end{array}$ & 1839.80 \\
\hline 2 & $\begin{array}{l}\text { Republic of } \\
\text { Korea }\end{array}$ & KOR & $\begin{array}{l}\text { High } \\
\text { income }\end{array}$ & 1642.40 & Malaysia & MYS & $\begin{array}{l}\text { Upper } \\
\text { middle } \\
\text { income }\end{array}$ & 364.70 \\
\hline 3 & State of Kuwait & KWT & $\begin{array}{l}\text { High } \\
\text { income }\end{array}$ & 134.80 & $\begin{array}{l}\text { Republic of } \\
\text { Albania }\end{array}$ & ALB & $\begin{array}{l}\text { Upper } \\
\text { middle } \\
\text { income }\end{array}$ & 5.7 \\
\hline 4 & New Zeeland & NZL & $\begin{array}{l}\text { High } \\
\text { income }\end{array}$ & 206.90 & $\begin{array}{l}\text { Russian } \\
\text { Federation }\end{array}$ & RUS & $\begin{array}{l}\text { Upper } \\
\text { middle } \\
\text { income }\end{array}$ & 1699.90 \\
\hline 5 & Switzerland & CHE & $\begin{array}{l}\text { High } \\
\text { income }\end{array}$ & 701.30 & $\begin{array}{l}\text { United } \\
\text { Republic of } \\
\text { Tanzania }\end{array}$ & TZA & $\begin{array}{l}\text { Upper } \\
\text { middle } \\
\text { income }\end{array}$ & 63.2 \\
\hline 6 & $\begin{array}{l}\text { United States of } \\
\text { America }\end{array}$ & USA & $\begin{array}{l}\text { High } \\
\text { income }\end{array}$ & 21374.40 & $\begin{array}{l}\text { Republic of } \\
\text { Belarus }\end{array}$ & BLR & $\begin{array}{l}\text { Upper } \\
\text { middle } \\
\text { income }\end{array}$ & 63.1 \\
\hline 7 & $\begin{array}{l}\text { Republic } \\
\text { Armenia }\end{array}$ & ARM & $\begin{array}{l}\text { High } \\
\text { income }\end{array}$ & 13.9 & $\begin{array}{l}\text { Republic of } \\
\text { Bulgaria }\end{array}$ & BGR & $\begin{array}{l}\text { Upper } \\
\text { middle } \\
\text { income }\end{array}$ & 67.9 \\
\hline 8 & $\begin{array}{l}\text { Kingdom of } \\
\text { Belgium }\end{array}$ & BEL & $\begin{array}{l}\text { High } \\
\text { income }\end{array}$ & 529.60 & $\begin{array}{l}\text { People's } \\
\text { Republic of } \\
\text { China }\end{array}$ & $\mathrm{CHN}$ & $\begin{array}{l}\text { Upper } \\
\text { middle } \\
\text { income }\end{array}$ & 14342.90 \\
\hline
\end{tabular}

Table 1: Focused countries and their GDP in the year 2019

\subsection{Outlier Detection}

Outlier problems have several reasons within the datasets of developed and developed countries. For instance, there might be a break in the input data series due to switching data from one source to another. This can affect the growth rate of countries. For instance, labor input in a particular year can bring changes to the economies. In this case, the GDP of a nation can indicate some critical findings. The process of outlier detection consists of the following steps:

First, we choose the countries randomly from the lists of developed and developing countries. This step includes countries with the data on ICT from 16 countries in the given period (2010-2019). However, 16 is not the magic number of countries and can be extended in future works. The second step is to ignore the erroneous or missing data in the GDP of 
chosen countries. There might be some countries, which have zero ICT capital compensation in a particular year. Therefore, visual inspection of GDP growth rate and other growth rate factors can reveal problematic observations. Hadi $(1992,1994)$ proposed a commonly used outlier detection method in the empirical literature. The purpose behind the outlier detection is to detect observations in the given datasets of 16 countries.

\subsection{Descriptive Statistics}

There are mainly three descriptive statistics: frequency, central tendency (median, mean, and mode), and dispersion or variation. The frequency is mostly applied to the categorical data, and other measurements are used for quantitative data.

Hypothesis 1.1: Global warming has become a danger for a human being; as countries grow in technological innovation and changes, more hazardous materials are added to the climate that can have adverse effects on the lives of human beings.

Why should climate changes be related to technological changes? Several studies advocate the proposal of greenhouse gas removal technologies (GGRTs) to help and meet the Paris agreement. Still, many issues remain to be resolved in the upcoming years. Goglio et al. (2020) reveal many uncertainties in estimating the effective greenhouse gas removal caused by the varying levels of technology development. Empirical evidence has grown in establishing the links between innovation and environmental policy. Most of the economic models call technology exogenous (Popp 2004).

Hypothesis 1.2: In developed countries, people are less likely affected by the adverse effects of climate changes, whereas in developing countries, GDP, PCI, and RD\&D factors are low in value compared to the developed countries.

Why should people be less impacted by the adverse effects of climate changes in developed countries? Developed countries conduct the assessment of the potential impacts of climate changes. They have their monitoring and surveillance programs capable of addressing and reduce threats of climate change (Panic and Ford 2013). A developed country 
might be having a high GDP and PCI as compared to a developed country. Therefore, people living in developed countries will make more expenses to prevent the adverse effects of climate changes.

\section{Results and Discussion}

To evaluate the growth indicators (GDP \& PCI) and technological expenses such as energy technology RD\&D budget in developed countries and compare them with the developing countries, it is informative to compare what had been experienced by the developed countries.

What today's developing countries are participating in the perspectives of earlier mentioned factors. There have been several studies that looked at the long term trends in climate changes (Lu et al., 2015; Uboni et al., 2016), and there was no so far attempt to analyze technological impacts on climate changes and compare these trends with those observed in developed and developing countries.

Figure 1 compares trends in developed and developing countries in the perspectives of global innovation index (GII) and innovation efficiency ratio (IER). The GII is aimed to create, utilize and diffuse knowledge to produce value that contributes to wealth creation (Al-Sudairi and Bakry, 2014). The activation of activities attracts attention as they build knowledge-based societies that promote a culture with economic and social benefits. GII is a barometer of the economy, and technological progress is the central part of innovation (Guillen and Deckert, 2021). Innovation efficiency is measured by a ratio between single input to single output values (Wang et al., 2016). Therefore, innovation input sub-index and innovation sub-index output values are illustrated in Figure 1. Trends presented in Figure 1 show a simple depiction of GII and IER indicators in two types of countries. A fascinating picture painted in Figure 1 as Australia and New Zeeland appears to be worrying about two innovation indicators. Switzerland (CHE) data has not been reported in the source of data, and therefore, two indicators are shown as zeros. 
Figure 1: Comparison of developed and developing countries regarding innovation indicators.

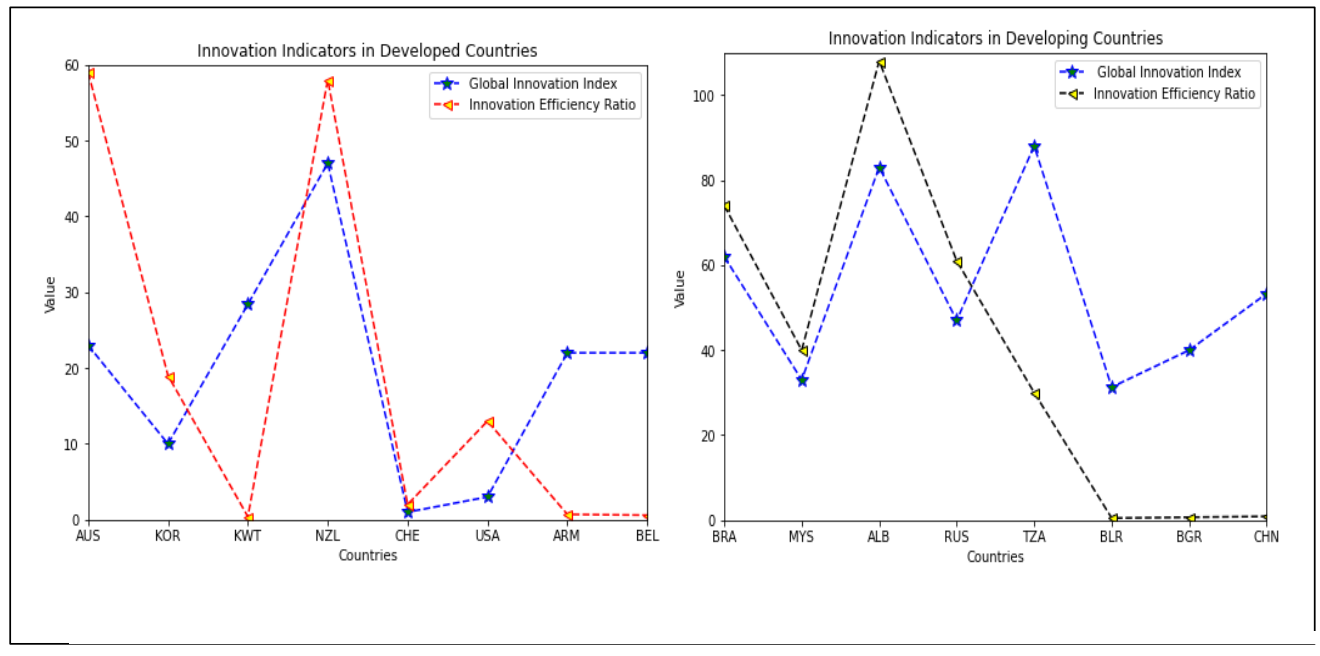

Among other developed countries, Armenia (ARM) and Belgium (BEL) have shown better GII indicators but still, show IER values below 1. Kuwait from the Gulf region also appears better in the list of developed countries regarding the GII indicator. The USA still has a lower GII and lagged behind AUS, NZL, KOR, KWT, ARM, and BEL countries for the observed values. In terms of the IER indicator, the USA still shows a lower IER value than AUS, KOR, NZL but higher values than KWT, ARM, and BEL countries. Hence, we may conclude that AUS, KOR, and NZL countries exceed what the USA has to confront in coming years. Given that the KOR and USA the lower GII values, further technological development may pose health challenges in these regions.

On the other hand, in developing countries (Figure 1), there is a dramatic increase in GII and IER values compared to developed countries. Except for BLR, BGR, and CHN, all other countries have shown similar trends in GII and IER values. BLR, BGR, and CHN showed a decline in IER values. This might be due to several factors that can be investigated in further research studies. In terms of both innovation indicators, overall, developing countries have a higher trend than developed countries. For instance, Albania (ALB) has a higher GII and IER value than the rest of developed countries and countries in developed economies. 
The results of our more formally tested hypothesis - the role of technological innovation and changes and their adverse impacts on human lives are given in the following.

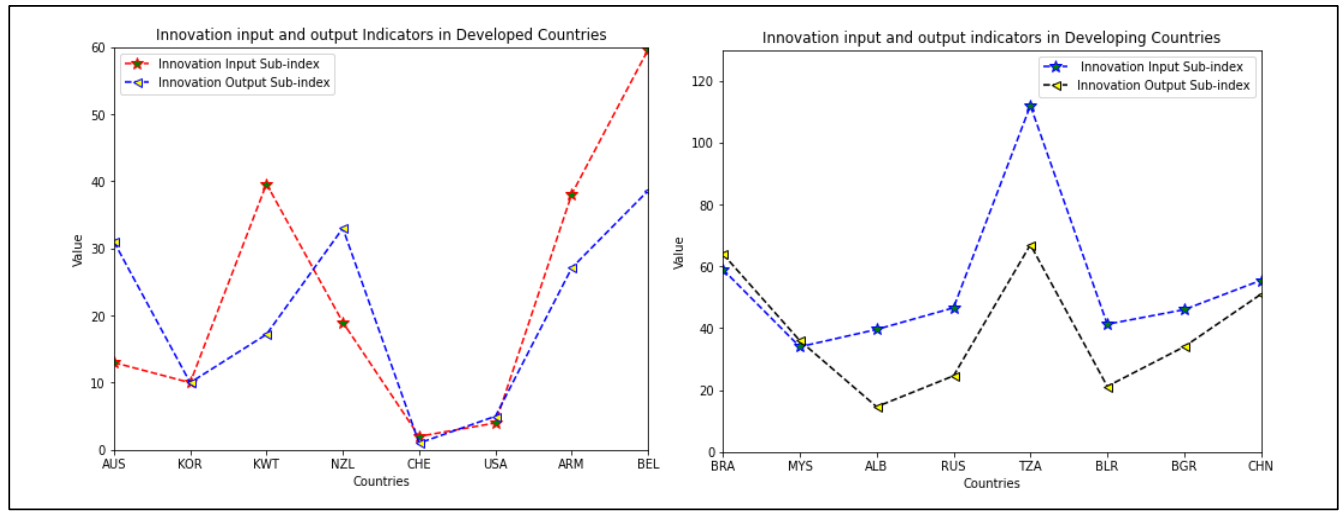

Figure 2: Innovation and sub-indicators in developed and developing countries

For the initial exploration, we use simple graphical illustrations (Figure 1). Let's look at trend lines in developed and developing countries. The simple analysis suggests that GII and IER values are more likely in developing countries than developed countries. As Figure 2 shows, Innovation Input Sub-index (IIS) and Innovation Output Sub-index (IOS) ratio that directly measures IER value is evidence that developed countries have higher values. However, we do not over-interpret and test our hypothesis 1.1 with the help of results from Figures (1-2). Nevertheless, the observed trends in patterns in Figures (1-2) confirm our findings derived from developed and developing economies.

A few compelling cases were reported and are worthy of highlighting: KOR contained similar IIS and IOS values from the Asia continent. On the other hand, another country (MYS) from Asian countries was also in the same situation, containing similar IIS and IOS values. They also used ISS and IOS indicators to provide information about outputs resulting from innovative economies (Magalhaes et al., 2019). 
In Figures (1-2), we examine how the trends may have appeared in developed and developing countries. Moreover, it seems that the peak level has been dramatically shifting to the developing countries, suggesting that high IIS and IER values can allow governments to switch to the descending trajectory for careful use of technology and technological changes in developing countries.

The results for hypothesis 1.2 are displayed in Figures (3-5): Figure 3 provides ICT, access, and use products in developed and developing economies. We used ICT and its two sub-indicators such as ICT access and ICT, to test hypothesis 1.2. - people are less likely affected by the adverse effects of climate changes in developed countries than the developing countries where GDP, and Total RD\&D budget factors are low in values.

Figure 3: ICT and sub-indices in developed and developing countries

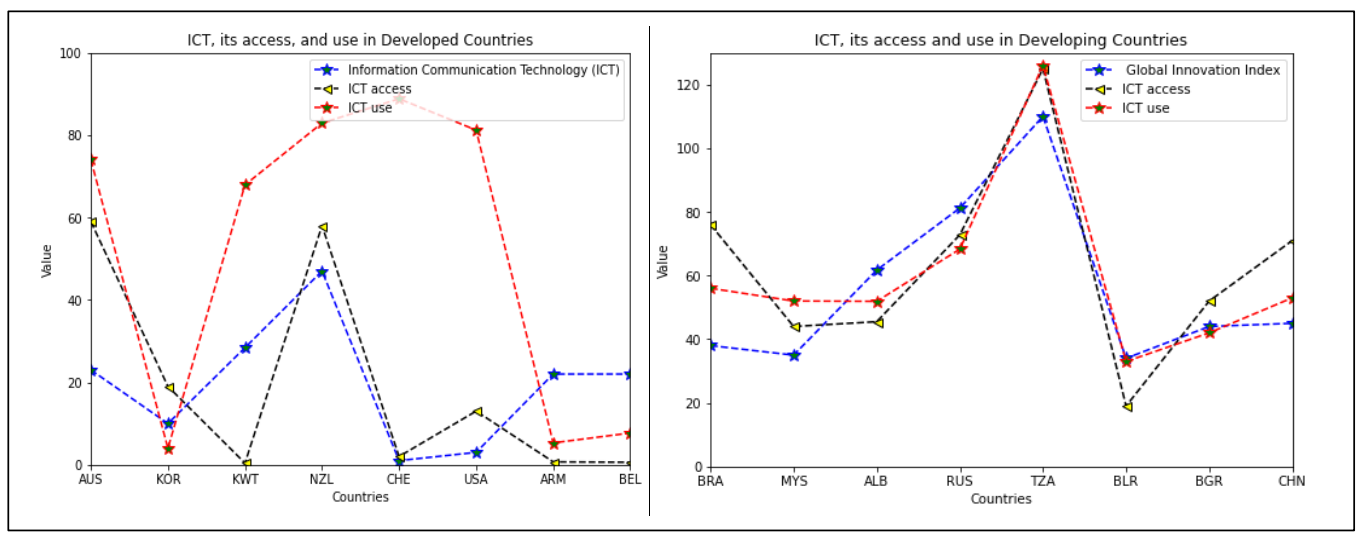

Figure 3 shows us ICT, its access, and its use in developed and developing economies. We find exciting results from Figure 3. Among developed economies, KOR, CHE, ARM, and BEL have shown values below 20 for these indicators. AUS, NZL have values above that, indicating a varying adoption of ICT in developed countries and wondering to note that KWT, CHE, ARM, and BEL have access to ICT resource. Still, the use of ICT is less than in other developed countries. The reason behind less use of ICT can be investigated to observe the situation arising from these countries. Hypothesis 1.2 considers differences of ICT, its access and use (service) within the country among developed economies, proxies by their technological changes, and their adverse 
effects. This hypothesis inspires us by shifting the burden of ICT from developed economies to developing economies. The theoretical explanation of hypothesis 1.2 can be justified to the countries' GDP as shown in Figure 4.

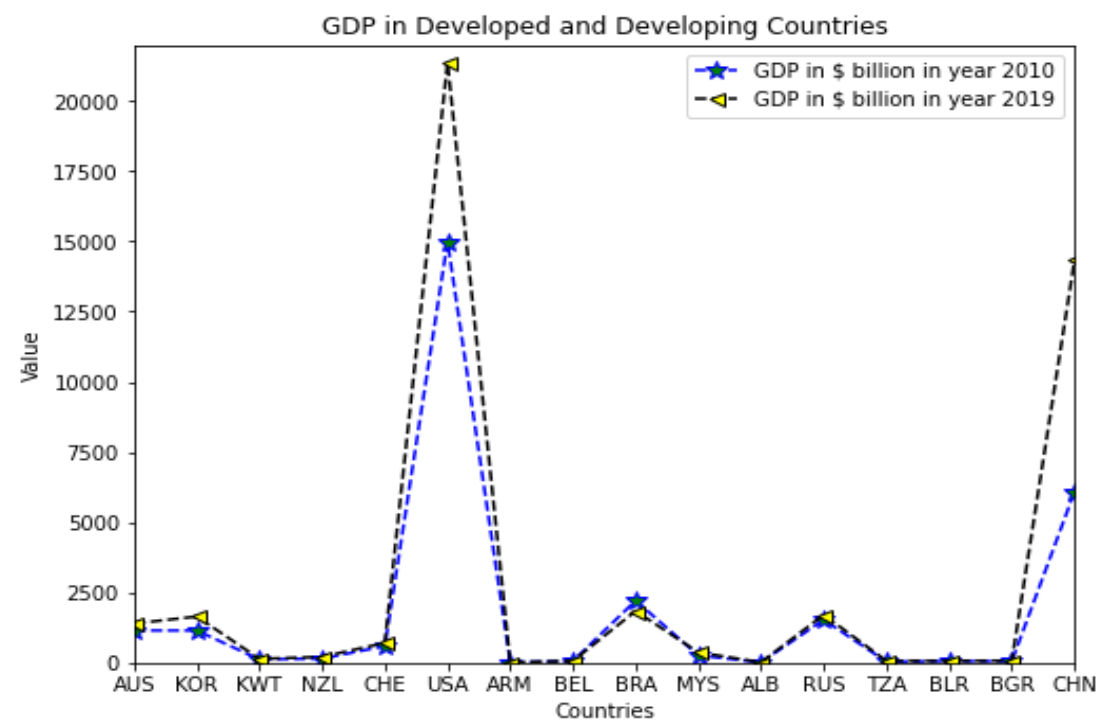

Figure 4: GDP in $\$$ billions in the chosen countries for years 2010, and 2019

Figure 4 shows us GDP in \$ billions in years 2010 and 2019 among the chosen countries. Countries like AUS, KOR, and CHE among developed economies; BRA and RUS among developing economies have below 2500 \$ billion GDP over the 2010 and 2019 years. At the same time, the USA and CHN economies have a higher GDP among all chosen countries. Both of these countries have a marginal differences between their GDP in 2010 and 2019 years. We find exciting GDP results with a similar trend over the chosen period for most nations. Countries such as KWT, NZL, and CHE, ARM, and BEL have negligible differences between their GDPs after a gap of 10 years. 


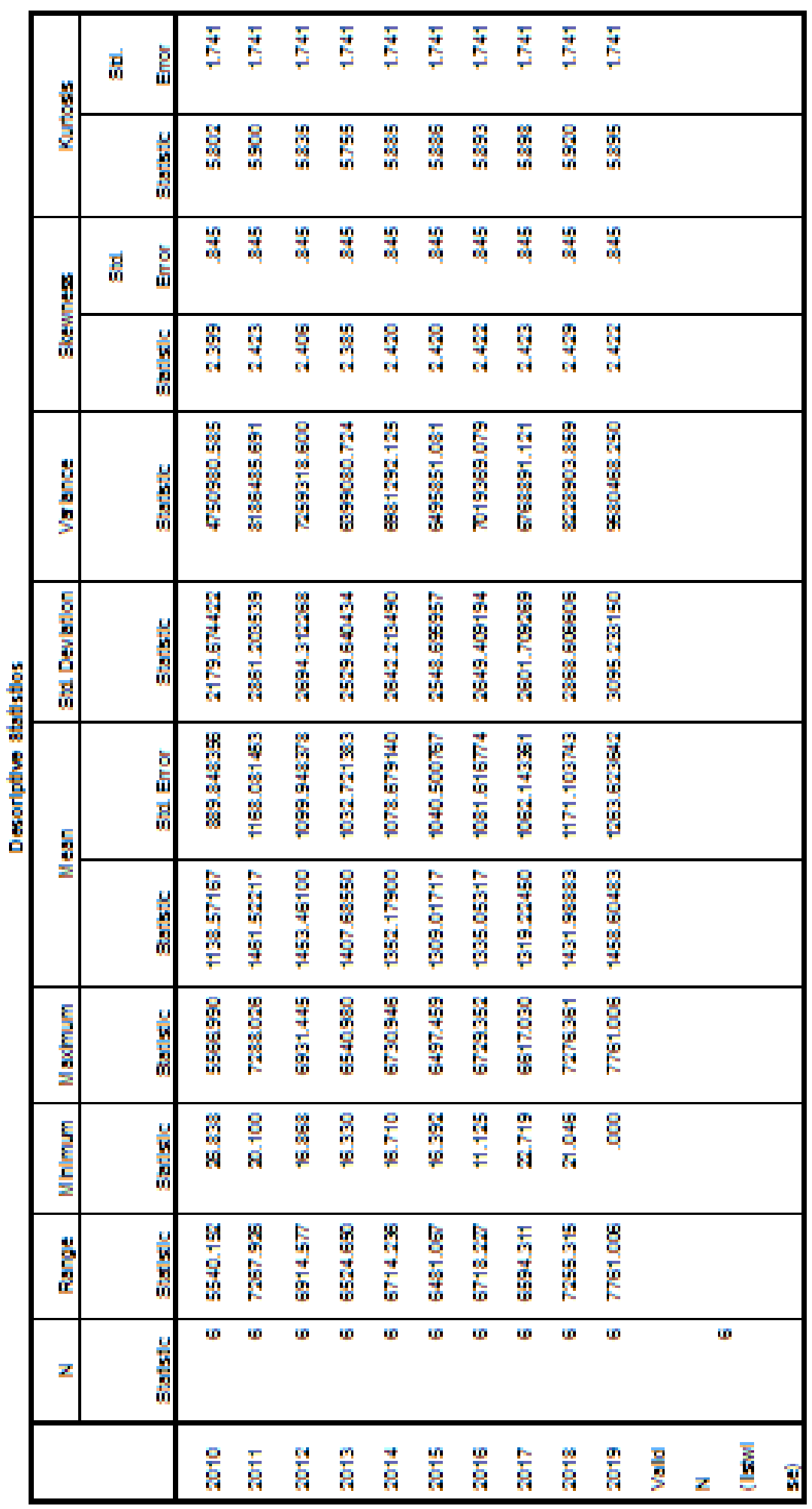

Table 2: Descriptive statistics 
Table 2 reports the descriptive statistics of six countries concerning RD\&D budgets for 2010-2019 from the lists of developed and developing countries. Before this study, several research works were focused on RD\&D programs. Chan et al. (2009) emphasized the RD\&D program to improve the understanding and familiarity of technology improvement. Under Paris Agreement, countries shown in Figure 5, and listed in Table 2, signed to double the investment on the RD\&D budget to reduce carbon emission up to zero. The agreement's purpose was to bring consistent and favorable cooperation in international energy technology, developing improved and cleaner innovation in renewable energy technology. With this scope, this research investigates whether the RD\&D budget allocated to these countries in the energy field brought convergence to some extent.

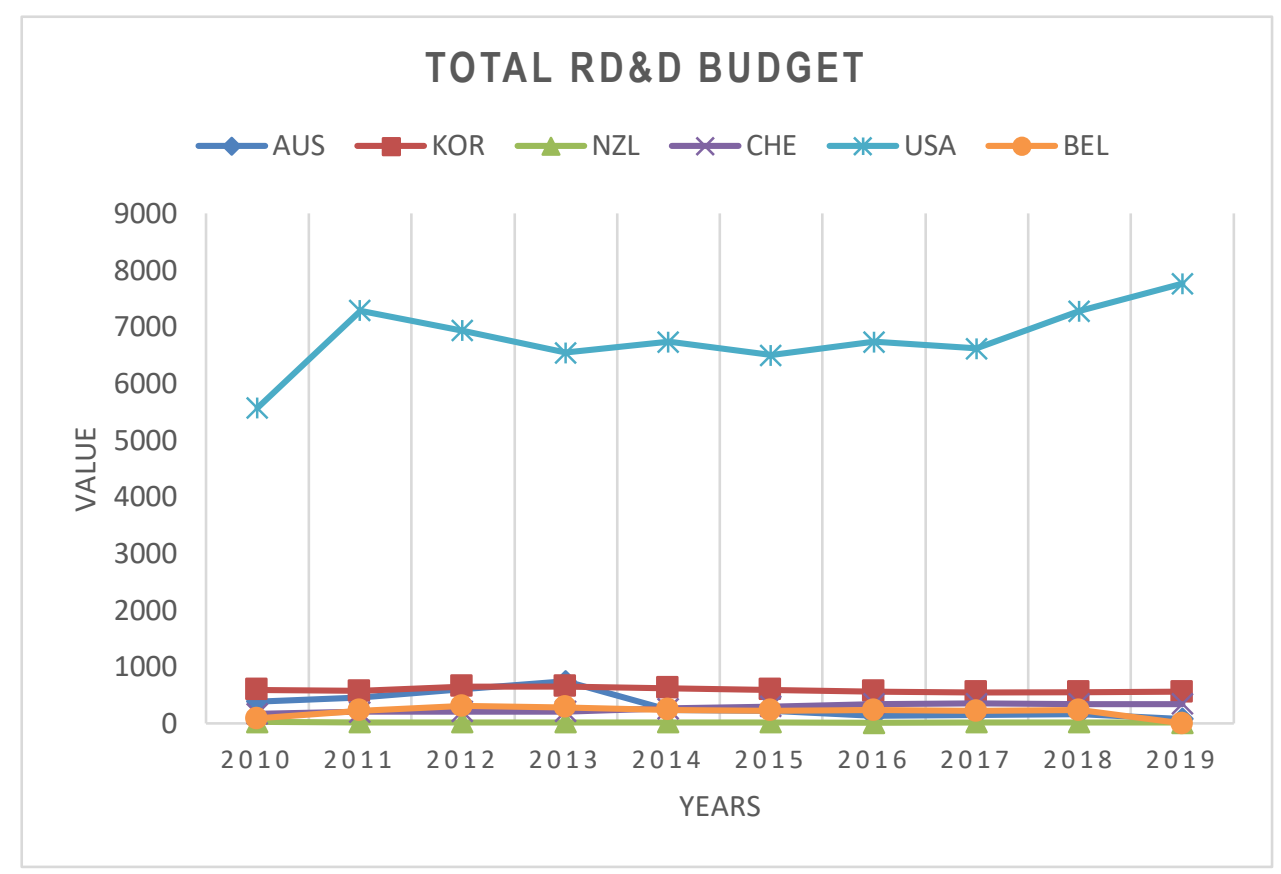

Figure 5: Total RD\&D budget distribution throughout 2010-2019

The estimation policy adopted in this research is based on two steps. The first step is to test hypothesis 1.2. The second step aims to check whether RD\&D budget allocation is linear, meaning that consistency in RD\&D budget saves countries from adverse effects of climate changes. In that case, the hypothesis is accepted, and the statements in hypothesis 1.2 are valid. If there is nonlinearity in the allocation of the RD\&D budget, we may reject the hypothesis. This study's findings suggest that the total 
RD\&D budget follows a linear path (Figure 5). We tested hypothesis 1.2, assuming a linear process of RD\&D budget allocation. The estimation results listed in Table 2 and shown in Figure 5 fail to reject hypothesis 1.2, indicating that chosen countries do not diverge in their budgets devoted to total RD\&D budget in energy and technology sectors. However, the outcomes reflect disparities in the RD\&D budget of Australia (AUS) and the rest of the countries. Since RD\&D budget allocation in energy technology in all of these countries follows a stationary process, spending shocks will not have persistent effects on the installation of cleaner energy, resulting in no delay in the low-carbon transition.

The concept of skewness is used to measure the symmetry of the distribution. The distribution of the curve is symmetric on either side of a central point. If this does not happen, then it is called skewness. On the other hand, Kurtosis represents the outliers (Kaliyadan and Kulkarni 2019). If there is a distribution with the high Kurtosis, indicating many outliers, while low Kurtosis, indicating lesser outliers. Results presented in Table 2 have enormous skewness (2.429) and Kurtosis (5.920) values, meaning that the distribution was peaked with the longer right-tailed curve for Total RD\&D budget allocation for the chosen countries.

\section{Conclusions and Implications}

This paper investigates climate changes occurring due to technological changes derived from high GDP, ICT access and use, Total RD\&D budget allocations in developed and developed countries. Empirical analysis of Panel data over the years 2010 to 2019 from the Paris agreement has been used to test the hypothesis. Most of the studies focused on technological changes in the perspective of country-specific, and no comparison have been performed on the data of developed and developing countries. By taking advantage of the latest data from previous studies, we examined the recent information on the earlier mentioned indicators by testing hypotheses. Our study confirmed a set of hypotheses about the association between innovation, ICT, and Total RD\&D indicators, climate changes, and their consequent adverse effects on human living in two categories of countries. 
The findings of this study suggest a few research and policy implications: The first research implication is to collect and analyze data on the Total RD\&D budget allocation in developing economies over the past few years. The second research implication is to investigate how developed and developing economies can help in mitigating the adverse effects of climate changes in low-income countries. The main policy implication is to equally distribute and allocate the RD\&D budget according to the economic situation of each country throughout the world.

One additional issue is worth mentioning. The present dataset covers the majority of data of developed countries. For example, Total RD\&D budget allocation is only given for developed countries; therefore, a bias in selecting countries might be present, resulting in the generalization of results, which are only valid to some extent.

\section{Disclosure statement}

No potential conflict of interest was reported by the authors.

\section{Email address:}

faig88@inbox.ru 


\section{References and notes:}

Al-Sudairi, M., \& Haj Bakry, S. (2014). Knowledge issues in the global innovation index: Assessment of the state of Saudi Arabia versus countries with distinct development. Innovation, 16(2), 176-183.

Asghar, N., Anwar, A., Rehman, H. U., \& Javed, S. (2019). Industrial practices and quality of the environment: evidence for Asian economies. Environment, Development and Sustainability, 22, 1-23.

Badunenko, O., Henderson, D. J., \& Zelenyuk, V. (2008). Technological change and transition: relative contributions to worldwide growth during the 1990s. Oxford Bulletin of Economics and Statistics, 70(4), 461-492.

Büber Kaya, H., Kaya.O.(2020). Tag based recommendation system of a Social networking site. International Journal of Humanities and Social Development Research.Volume 4, Number 2,(36-51).Azerbaijan.http://doi.org:10.30546/25234331.2020.4.2.36

Cecere, G., Rexhauser, S., \& Schulte, P. (2019). From less promising to green? Technological opportunities and their role in (green) ICT innovation. Economics of Innovation and New Technology, 28(1), 45-63.

Chan, G., Anadon, L. D., Chan, M., \& Lee, A. (2011). Expert elicitation of cost, performance, and RD\&D budgets for coal power with CCS. Energy Procedia, 4, 2685-2692.

Comin, D. A., Dmitriev, M., \& Rossi-Hansberg, E. (2012). The spatial diffusion of technology (No. w18534). National Bureau of Economic Research.

Court, V. (2018). Energy Capture, Technological Change, and Economic Growth: An Evolutionary Perspective. BioPhysical Economics and Resource Quality, 3, 127.

Goglio, P., Williams, A. G., Balta-Ozkan, N., Harris, N. R., Williamson, P., Huisingh, D., ... \& Tavoni, M. (2020). Advances and challenges of life cycle assessment (LCA) of greenhouse gas removal technologies to fight climate changes. Journal of Cleaner Production, 244, 118896.

Guillén, V. I. N., \& Deckert, C. (2021). Cultural influence on innovativeness-links between "The Culture Map" and the "Global Innovation Index". International Journal of Corporate Social Responsibility, 6(1), 1-12.

Hansen, B. E. (2000). Sample splitting and threshold estimation. Econometrica, 68(3), $575-603$.

Hornborg, A. (2014). Ecological economics, Marxism, and technological progress: Some explorations of the conceptual foundations of theories of ecologically unequal exchange. Ecological Economics, 105, 11-18.

Kaliyadan, F., \& Kulkarni, V. (2019). Types of variables, descriptive statistics, and sample size. Indian dermatology online journal, 10(1), 82.

Kitchin, R., \& Thrift, N. (2009). International encyclopedia of human geography. Elsevier.

Kumar, S., \& Russell, R. R. (2002). Technological change, technological catch-up, and capital deepening: relative contributions to growth and convergence. American Economic Review, 92(3), 527-548.

Lu, H., Bryant, R. B., Buda, A. R., Collick, A. S., Folmar, G. J., \& Kleinman, P. J. (2015). Long-term trends in climate and hydrology in an agricultural, headwater watershed of central Pennsylvania, USA. Journal of Hydrology: Regional Studies, 4, 713-731.

Magalhães, K. E., Portes, J. H., Domenech, A. M., \& Junqueira, L. A. P. (2019). Impacts of Corruption on Innovation and Well-Being on Countries Represented in the ICIM by OECD members. Journal on Innovation and Sustainability RISUS, 10(4), 4-15. 
Marangoni, G., \& Tavoni, M. (2014). The clean energy R\&D strategy for 2 C. Climate Change Economics, 5(01), 1440003.

Naqvi, A., \& Stockhammer, E. (2018). Directed technological change in a post-Keynesian ecological macromodel. Ecological economics, 154, 168-188.

Niebel, T. (2018). ICT and economic growth-Comparing developing, emerging and developed countries. World Development, 104, 197-211.

Novak, Z. (2020). Structural Change in Central and South Eastern Europe-Does Technological Efficiency Harm the Labour Market? Sustainability, 12(11), 4704.

Oh, C. (2019). Political economy of international policy on the transfer of environmentally sound technologies in global climate change regime. New Political Economy, 24(1), 22-36.

Panic, M., \& Ford, J. D. (2013). A review of national-level adaptation planning with regards to the risks posed by climate change on infectious diseases in 14 OECD nations. International journal of environmental research and public health, 10(12), 7083-7109.

Popp, D. (2004). ENTICE: endogenous technological change in the DICE model of global warming. Journal of Environmental Economics and management, 48(1), 742-768.

Schwartzman, D. (2008). The limits to entropy: Continuing misuse of thermodynamics in environmental and Marxist theory. Science \& Society, 72(1), 43-62.

Tsai, J. M., Chang, C. C., \& Hung, S. W. (2018). Technology acquisition models for fast followers in high-technological markets: an empirical analysis of the LED industry. Technology Analysis \& Strategic Management, 30(2), 198-210.

Uboni, A., Horstkotte, T., Kaarlejärvi, E., Sévêque, A., Stammler, F., Olofsson, J., ... \& Moen, J. (2016). Long-term trends and role of climate in the population dynamics of Eurasian reindeer. PloS one, 11(6), e0158359.

Vega, S. H., \& Mandel, A. (2018). Technology diffusion and climate policy: a network approach and its application to wind energy. Ecological Economics, 145, 461471.

Wang, Q., Hang, Y., Sun, L., \& Zhao, Z. (2016). Two-stage innovation efficiency of new energy enterprises in China: A non-radial DEA approach. Technological Forecasting and Social Change, 112, 254-261. 


\title{
XÜLASə
}

\section{İnkişaf etmiş və inkişaf etməkdə olan iqtisadiyyatda texnoloji dəyişikliklər və ekoloji nəticələr}

\author{
Faiq Ăgabalayev \\ Siçuan Universiteti, Çin Xalq Respublikası \\ Jiang Xiao Ran \\ Siçuan Universiteti, Çin Xalq Respublikası
}

İnkişaf etmiş və inkişaf etməkdə olan ölkələrdə iqlim dəyişiklikləri texnoloji dəyişikliklərin artması nəticəsində baş verir. İqlim dəyişiklikləri bütün dünyada insanların həyatı üçün ciddi nəticələrə səbəb ola bilər. Dünyanın inkişaf etmiş və inkişaf etməkdə olan ölkələrin iqtisadiyyatlarında mövcud olan ən son texnoloji dəyişikliklər, onların iqlimə təsirləri haqqında geniş mənzərəni göstərmir.

$\mathrm{Bu}$ məqalə dünyanın aparıcı inkişaf etmiş iqtisadiyyatlarda dinamik texnoloji dəyişiklikləri araşdırır vo onların nəticələrini, artım göstəricilərinə olan mənfi təsirlərini müqayisə edir. Elmi təhlil, Paris razılaşmasına əsasən 2010-2019-cu illər üçün toplanmış məlumatlar üzərində aparılır. Nəticələr inkişaf etmiş ölkələrdə informasiya kommunikasiya texnologiyalarının (İKT) dəyişən bir şəkildə qəbulunu göstərdi. Tədqiqatın nəticələri texnologiyanın geniș istifadəsi nəticəsində baş verən xoşagəlməz ekoloji vəziyyətin qarşısını almaq üçün problemi diqqət mərkəzində saxlamaqla yanaşı, digər ölkələr üçün faydalıdır.

$\mathrm{Bu}$ araşdırmanın nəticələri bir neçə istiqamətləri göstərərək, qlobal miqyasda ekoloji şəraitin yaxşılaşdırılması üçün bir neçə yeni istiqamətlər də təklif etmişdir.

Açar sözlər: Informasiya kommunikasiya texnologiyaları (IKTT); ümumi daxili məhsul (ÜDM); qlobal innovasiya indeksi (GII); hipotez testi. 


\title{
PEЗЮME
}

\section{Технологические изменения и экологические последствия в развитых и развивающихся экономиках}

\author{
Файк Агабалаев \\ Сычуаньский университет, Китайская Народная Республика \\ Цзян Сяо Ран \\ Сычуаньский университет, Китайская Народная Республика
}

В развитых и развивающихся странах изменение климата усиливается в результате технологических изменений. Изменение климата может иметь серьезные последствия для жизни людей во всем мире. Последние технологические изменения в экономике развитых и развивающихся стран не дают полной картины их воздействия на климат. В данной статье исследуются динамические технологические изменения в ведущих развитых странах мира и сравниваются их результаты и негативное влияние на темпы роста.Научный анализ основан на данных, собранных за 2010-2019 годы в рамках Парижского соглашения. Результаты показали, что внедрение информационных и коммуникационных технологий (ИКТ) в развитых странах меняется.Результаты исследования полезны для других стран, сохраняя при этом проблему в центре внимания, чтобы предотвратить неблагоприятную экологическую ситуацию, вызванную широким использованием технологий.

По результатам исследования предлагается несколько направлений, а также несколько новых направлений улучшения экологической ситуации в глобальном масштабе.

Ключевые слова: Информационные и коммуникационные технологии (ИКТ); валовой внутренний продукт (ВВП); глобальный инновачионный индекс (ГИИ); проверить гипотезу.

ELM VO İNNOVATIV TEXNOLOGIYALAR JURNALI 